\title{
PENGARUH PENAMBAHAN RAMUAN HERBAL PADA AIR MINUM TERHADAP PERSENTASE KARKAS, PERSENTASE LEMAK ABDOMEN DAN PERSENTASE HATI PADA AYAM KAMPUNG SUPER
}

\author{
Yanter Tahalele, Martina E. R. Montong*, Fredy J. Nangoy, Cherlie L. K. Sarajar \\ Fakultas Peternakan Universitas Sam Ratulangi Manado
}

\begin{abstract}
ABSTRAK
Penelitian ini bertujuan untuk mengetahui seberapa besar pengaruh ramuan herbal yang ditambahkan dalam air minum terhadap persentase karkas, persentase lemak abdomen dan persentase hati pada ayam kampung super. Materi yang digunakan adalah 84 ekor ayam kampung super jantan umur 5 minggu. Tanaman herbal yang digunakan adalah bawang putih (Allium sativum L.), kencur (Kaempferia galangal L.), kunyit (Curcuma domestika Val.), temulawak (Curcuma xanthorhiza roxb), jahe (Zingiber officinale roscoe), daun sirih (Piper better Linn), daun mahkota dewa (Phaleria macrocarpa Boerl). Tanaman herbal diekstrak, dicampur dengan gula aren dan difermentasi dengan EM4. Metode yang digunakan adalah rancangan acak lengkap yang terdiri dari tiga perlakuan dan tujuh ulangan, perlakuan diberikan dalam air minum dengan masing - masing perlakuan adalah $\mathrm{R}_{0}=$ air minum tanpa penambahan ramuan herbal, $\mathrm{R}_{1}=1$ liter air mimum $+2,5 \mathrm{~mL}$ ramuan herbal, $\mathrm{R}_{2}=1$ liter air minum $+5 \mathrm{~mL}$ ramuan herbal. Hasil analisis menunjukan bahwa penambahan ramuan herbal $2,5 \mathrm{~mL}$ dan 5 $\mathrm{mL}$ pada air minum memberikan pengaruh tidak nyata $(\mathrm{P}>0.05)$ terhadap persentase karkas dan persentase hati, Sedangkan untuk variabel lemak abdomen, penambahan herbal 2,5 dan $5 \mathrm{~mL}$ memberikan pengaruh sangat nyata $(\mathrm{P}<$ 0.01). Kesimpulannya adalah bahwa pemberian ramuan herbal sampai $5 \mathrm{~mL}$
\end{abstract}

*Korespondensi (corresponding Author)

Email: martinamontong@gmail.com yang ditambahkan pada air minum tidak menyebabkan perubahan persentase karkas dan persentase hati namun pada pemberian $5 \mathrm{~mL}$ terjadi penurunan persentase lemak abdomen ayam kampung super.

Kata kunci: ayam kampung super, ramuan herbal, persentase karkas, persentase lemak abdomen, persentase hati.

\section{ABSTRACT}

THE EFFECT OF ADDITION OF RAMUAN IN DRINKING WATER ON CARCASS PERCENTAGE, ABDOMEN FAT PERCENTAGE AND HEART PERCENTAGE OF AYAM KAMPUNG SUPER. The purpose of this study was to determine the effect of herbs mixed in water added to percentage of carcass, fat abdomen and heart of "ayam kampung super". This research used a 84 of chicken at five weeks old. The Herbs were garlic (allium sativum 1.), kencur (kaempferia galangal 1.), turmeric (curcuma domestika val.), temulawak (curcuma xanthorhiza roxb), ginger (zingiber officinale roscoe), leaf leaves (piper better linn) and mahkota dewa (phaleria macrocarpa boerl). The extracted herbs were mixed with palm sugar and fermented with EM4. The complete randomized design consist of 3 treatments and 7 replications were used as methods. The treatment were formulated as follow $\mathrm{R}_{0}$ $=$ drinking water without addition of herbs, $\mathrm{R}_{1}=1$ liter water +2.5 of $\mathrm{mL}$ herbs, $\mathrm{R}_{2}=1$ liter drinking water $+5 \mathrm{~mL}$ of herbs. Research result showed that the addition of herbs $2.5 \mathrm{~mL}$ and $5 \mathrm{~mL}$ in drinking water shows no significant effect $(\mathrm{P}>0.05)$ on the 
percentage of carcass and liver percentage, but there was an increase in the percentage of carcass in treatment of $\mathrm{R}_{1}$ and $\mathrm{R}_{2}$. While the treatment gave a high significantly effect $(P<0.01)$ on the percentage of abdominal fat. The conclusion of this research is the giving of herbs up to $5 \mathrm{~mL}$ added to drinking water does not cause the percentage change of carcass and liver percentage but the giving $5 \mathrm{~mL}$ of herbs decrease of abdominal fat percentage of "ayam kampung super".

Key words: Super local chicken, herbs, percentage carcass, percentage of abdominal fat, percentage liver.

\section{PENDAHULUAN}

Peternakan di Indonesia seiring berjalannya waktu mulai mengalami peningkatan dalam berbagai sektor di bidang peternakan, baik peternakan modern maupun peternakan secara tradisional. Keadaan ini didorong oleh meningkatnya kesadaran masyarakat akan kebutuhan gizi yang bersumber dari hewani, salah satunya berasal dari daging ayam kampung super. Ayam kampung super atau ayam lokal pedaging unggul merupakan hasil persilangan antara ayam kampung dengan ayam ras jenis petelur (Sani, 2016). Selain memiliki kandungan gizi yang dibutukan oleh manusia, ayam kampung super juga memiliki masa pemeliharaan yang pendek dengan kualitas karkas yang baik dibandingkan dengan ayam kampung lokal.
Untuk mendapatkan ayam dengan karkas yang baik dengan kadar lemak rendah memerlukan manajemen pemeliharaan dan pemberian pakan yang sesuai. Pemanfaatan tanaman-tanaman herbal seperti bawang putih, lengkuas, jahe, kencur, kunyit, temulawak, daun sirih dan daun mahkota dewa, ternyata lebih efektif dalam menghasilkan kualitas karkas yang baik, selain itu bahan-bahan tersebut murah dan mudah didapat. Ramuan herbal juga memiliki khasiat untuk kesehatan ternak dan manusia sebagai konsumen daging ayam. Kandungan minyak astiri dan kurkumin sebagai zat bioaktif dalam ramuan herbal dapat merangsang keluarnya getah pankreas dan akan mengeluarkan enzim lipase yang dapat memecah asam lemak gliserol sehingga lemak yang terbentuk berkurang. Apritar (2012) menyatakan bahwa pemberian ramuan herbal cenderung meningkatkan persentase karkas serta menurunkan kadal lemak abdomen pada ayam. Selain menurukan kadar lemak abdomen, ramuan herbal juga dapat meningkatkan persentase karkas serta meningkatkan fungsi hati dalam mengemulsi zat-zat beracun yang terkandung dalam tubuh ayam. Bahanbahan ramuan herbal sumber difermentasi menggunakan EM4 (Effective Microorganisme 4) menurut petunjuk Zainuddin (2006). EM4 terdiri dari bakteri 
fotosintetik, bakteri asam laktat, ragi, aktinomydetes, dan jamur peragian tetapi 95\% berisi bakteri Lactobacillus yang berfungsi menguraikan bahan organik namun tidak menimbulkan suhu panas yang tinggi dalam proses fermentasi secara tertutup karena mikroorganisme anaerob bekerja dengan kekuatan enzim.

Berdasarkan gambaran diatas, maka telah dilakukan suatu penelitian mengetahui sejauh mana pengaruh ramuan herbal yang ditambahkan dalam air minum terhadap persentase karkas, persentase lemak abdomen dan persentase hati.

\section{MATERI DAN METODE PENELITIAN}

Ternak yang digunakan dalam penelitian ini adalah ayam kampung super jantan umur 5 minggu sebanyak 84 ekor. Kandang yang digunakan adalah kandang tipe baterai yang sudah dicuci dan di desinfektan, dengan ukuran kandang $60 \mathrm{~cm}$ $\times 40 \mathrm{~cm} \times 45 \mathrm{~cm}$ yang terdiri dari 21 unit dan setiap unit kandang ditempati 4 ekor ayam. Pakan yang digunakan adalah komersil atau pabrikan dengan kode CP 12 produk PT. Charoen Pokphand Indonesia. Penelitian ini dilakukan selama 6 minggu.

Proses pembuatan ramuan herbal yaitu menggunakan tanaman-tanaman herbal seperti bawang putih (250 g), kencur
(250 g), jahe (150 g), lengkuas (150 g), kunyit (150 g), temulawak (150 g), kayu manis $(62,5 \mathrm{~g})$, daun sirih $(62,5 \mathrm{~g})$, daun mahkota dewa $(62,5 \mathrm{~g})$ yang sudah dicuci bersih, kemudian diblender (digiling) hingga halus, setelah itu disaring pisahkan ekstrak dari ampas, tambahkan 10 liter air bersih kemudian difermentasi dengan campuran gula merah dan EM 4 (Effective Microorganisme) selama 7 hari (Zainuddin, 2006).

Penelitian terbagi atas 3 perlakuan dan 7 ulangan, pada masing-masing ulangan terdiri dari 4 ekor. Perlakuan yang berikan $\mathrm{R}_{0}$ : air minum tanpa ditambahkan ramuan herbal $(0 \mathrm{~mL}), \mathrm{R}_{1}: 1$ liter air minum $+2,5 \mathrm{~mL}$ ramuan herbal dan $\mathrm{R}_{2}: 1$ liter air minum $+5 \mathrm{~mL}$ ramuan herbal. Selama pemeliharaan ternak diberi pakan dan air minum secara ad libitum. Waktu pemeliharaan selama 6 minggu. Setelah itu ternak dipotong dan diambil karkas serta bahan lainnya untuk diukur.

\section{Variable Yang Diamati (Mustaqim, 2006).}

\section{Persentase Karkas}

Diperoleh dari hasil perbandingan antara berat karkas (gram) dengan berat hidup (gram) dikalikan $100 \%$.

Persentase karkas $=\frac{\text { berat karkas }}{\text { berat hidup }} \times 100 \%$ 
2. Persentase Lemak Abdomen (Mustaqim, 2006).

Diperoleh dari hasil perbandingan antara berat lemak abdomen (gram) dengan berat hidup (gram) dikalikan $100 \%$.

Persentase lemak abdomen

$$
=\frac{\text { berat lemak }}{\text { berat hidup }} \times 100 \%
$$

3. Persentase Hati

Diperoleh dari perbandingan antara berat hati (gram) dengan berat hidup (gram) dikalikan 100\%.

Persentase hati $=\frac{\text { berat hati }}{\text { berat hidup }} \times 100 \%$

\section{Analisis Data}

Data yang diperoleh dianalisis ragam menggunakan rancangan acak lengkap (RAL) dilanjutkan dengan uji lanjut Beda Nyata Jujur (BNJ) menurut petunjuk Steel dan Torrie, 1991.

\section{HASIL DAN PEMBAHASAN}

\section{Pengaruh Penambahan Ramuan Herbal Pada Air Minum Terhadap Persentase Karkas}

Hasil analisis keragaman menunjukan bahwa perlakuan tidak memberikan pengaruh yang nyata $(\mathrm{P}>0,05)$ terhadap persentase karkas. Hal ini menunjukkan bahwa perlakuan memberikan respons yang sama terhadap prosentase karkas. Seperti pernyataan Daud et al. (2007) perlakuan pemberian probiotik dan prebiotik dalam ransum tidak mampu mengubah persentase karkas secara signifikan.

Rataan persentase karkas yang diperoleh dalam penelitian ini berdasarkan metode "Ready To Cook" (tubuh ayam tanpa bulu, kepala, kaki, jeroan, kecuali hati, rempela, dan jantung) adalah 68,40 $70,08 \%$ (Tabel 1). Persentase karkas dalam penelitian ini masih lebih tinggi dibandingkan dengan hasil penelitian yang dilakukan Ramdani et al. (2016) dimana persentase karkas ayam kampung umur 12 minggu berkisar antara $62,48 \%-63,57 \%$ dengan pemberian pakan tepung ampas kelapa. Selain itu masih lebih tinggi dari persentase karkas ayam kampung dalam penelitian Bakrie et al. (2003) dengan kisaran antara 64,0\% - 68\% dari bobot hidup, dengan penambahan jamu kedalam air minum.

Walaupun hasil analisis statistik tidak berbeda nyata namun ada kecenderungan peningkatan persentase karkas pada perlakua $\mathrm{R}_{1}$ dengan penambahan $2,5 \mathrm{~mL}$ ramuan herbal per liter air yaitu $(69,78 \%)$ dan perlakuan $\mathrm{R}_{2}$ penambahan $5 \mathrm{~mL}$ ramuan herbal per liter air sebesar $(70,08 \%)$ yang dibandingkan dengan perlakuan kontrol $\left(\mathrm{R}_{0}=68,40 \%\right)$ Tabel 1. Hal ini sejalan dengan pernyataan dari Syam (2015) bahwa secara analisis pemberian jamu herbal tidak memberikan perbedaan 
Tabel 1. Rataan persentase karkas, persentase lemak abdomen dan persentase hati ayam kampung super yang ditambahkan ramuan herbal dalam air minum.

\begin{tabular}{lccc}
\hline \multirow{2}{*}{ Variabel } & \multicolumn{3}{c}{ Perlakuan } \\
\cline { 2 - 4 } & R0 & R1 & R2 \\
\hline Persentase Karkas & 68,40 & 69,78 & 70,08 \\
Persentase Lemak Abdomen & $0,73^{\mathrm{a}}$ & $0,21^{\mathrm{b}}$ & $0,1^{\mathrm{c}}$ \\
Persentase Hati & 2,01 & 1,83 & 1,78 \\
\hline
\end{tabular}

Keterangan: Nilai pada baris yang sama dengan superskrip yang berbeda menunjukan perbedaan sangat nyata $(\mathrm{P}<0,01)$.

nyata terhadap persentase karkas namun persentase karkas tertinggi diperoleh pada perlakuan dengan tanaman herbal yaitu daun sirih. Diduga karena zat bioaktif dalam ramuan herbal memiliki efek dari kombinasi bahan yang bersifat saling melengkapi (sparing effect), memberikan dampak positif terhadap beberapa parameter performans seperti karkas (Agustina, 2006). Menurut Harlin (2013) Kandungan zat bioaktif dalam ramuan herbal berupa minyak atsiri, kurkumin. Selain itu quersetin dan alisin pada bawang putih dalam ramuan herbal berfungsi sebagai antibakteri dalam tubuh (Dharmawati et al., 2013). Perbandingan persentase karkas dari ketiga perlakuan tersebut dapat menggambarkan bahwa perlakuan pemberian ramuan herbal dengan dosis $2,5 \mathrm{~mL}-5 \mathrm{~mL}$ per liter air minum, dapat dimanfaatkan untuk ayam kampung super.

\section{Pengaruh Penambahan Ramuan Herbal Pada Air Minum Terhadap Persentase Lemak Abdomen}

Hasil analisis ragam menunjukan bahwa pemeberian ramuan herbal yang ditambahkan dalam air minum memberikan pengaruh sangat nyata $(\mathrm{P}<0,01)$ terhadap persentase lemak abdomen. Hasil uji lanjut dengan BNJ menunjukan bahawa setiap perlakuan menunjukan perbedaan persentase lemak abdomen yang sangat nyata, antara perlakuan $\mathrm{R}_{0}$ (tanpa herbal) dengan perlakuan $\mathrm{R}_{1}$ (herbal 2,5 $\mathrm{mL}$ ) dengan perlakuan $\mathrm{R}_{2}$ (herbal $5 \mathrm{~mL}$ ) dan antara perlakuan $\mathrm{R}_{1}$ (herbal 2,5 mL) dengan $\mathrm{R}_{2}$ (herbal $5 \mathrm{~mL}$ ). Hal ini memberikan indikasi bahwa semakin tinggi dosis yang ditambahkan dalam air minum akan dapat menurunkan persentase lemak abdomen.

Rataan persentase lemak abdomen ayam kampung super yang di penen pada umur 11 minggu dalam penelitian ini berkisar antara $0,1 \%-0,73 \%$ dimana persentase tertinggi berada pada perlakuan $\mathrm{R}_{2}$ dan persentase terendah berada pada perlakuan $\mathrm{R}_{0}$ (kontrol) pada Tabel 1. Hasil ini lebih rendah dari persentase lemak abdomen ayam kampung super umur 8 
minggu sekitar $1,18 \%$ - 1,70\% dari berat hidup (Djunu dan Saleh, 2015). Rendahnya persentase lemak dalam penelitian ini, menunjukan bahwa kandungan zat bioaktif dalam ramuan herbal seperti minyak atsiri (minyak terbang) dan kurkumin berfungsi dalam meningkatkan proses metabolisme dan pencernaan lemak. Hal ini seperti penyataan Agustina et al. (2014) perbaikan metabolisme melalui pemberian ramuan herbal secara tidak langsung akan meningkatkan performa ternak melalui zat bioaktif yang dikandungnya.

Zat bioaktif seperti minyak atsiri dan kurkumin yang berperan meningkatkan kerja organ pencernaan, merangsang dinding empedu mengeluarkan cairan empedu dan merangsang keluarnya getah pankreas yang mengandung enzim lipase untuk meningkatkan pencernaan lemak (Agustina, 2006). Selanjutnya Supomo et al. (2016) menyatakan bahwa kandungan minyak astiri merangsang keluarnya getah pankreas, dimana getah pankreas mengeluarkan enzim lipase yang dapat memecah asam lemak gliserol sehingga lemak yang terbentuk berkurang. Senyawa kimia yang ada dalam kunyit dalam ramuan herbal mampu menurunkan lemak dalam tubuh, berperan dalam proses sekresi empedu dan pankreas yang dikeluarkan lewat feses (Rahayu dan Budiman, 2005).

\section{Pengaruh Penambahan Ramuan Herbal Pada Air Minum Terhadap Persentase Hati}

Berdasarkan hasil analisis

keragaman menunjukan bahwa perlakuan tidak memberikan pengaruh yang nyata $(\mathrm{P}>0.05)$ terhadap persentase hati ayam kampung super. Hal Ini menunjukan bahwa pemberian ramuan herbal $2,5 \mathrm{~mL}$ dan $5 \mathrm{~mL}$ per liter air minum memberikan respon yang baik terhadap persentase hati karena tidak ada peningkatan persentase hati. Pembesaran atau pembekakan hati dapat disebabkan oleh racun yang terbawa oleh makanan Manuaba et al. (2017). Budiman et al. (2015) yang dikutip dari Nickel et al (1997) menyatakan bahwa ukuran, berat, konsistensi dan warna hati tergantung dari bangsa, umur dan status nutrisi individu ternak.

Rataan persentase hati ayam kampung super umur 11 minggu dari masing-masing perlakuan dalam penelitian ini berkisar antara $1,78 \%-2,01 \%$ (Tabel 1). Hasil ini lebih rendah dari persentase hati ayam kampung umur 12 minggu menurut Cahyono et al. (2012) dengan pemberian ransum yang mengandung tepung jahe, berkisar antara 2,33\% - 2,53\% dari bobot hidup. Persentase hati normal ayam menurut Resnawati(2010) yang dikutip 
dari Siregar et al. (1980) yaitu berkisar antara $31-51$ gram atau $1,70 \%-2,30 \%$ dari bobot hidup.

Rendahnya persentase hati ayam kampung super dalam penelitian ini disebabkan karena kadar lemak dalam darah berkurang sehigga fungsi hati dalam mengsekresikan lemak darah tidak terlalu tinggi. Pengurangan deposit lemak tubuh ayam, termasuk lemak abdomen terjadi akibat perurunan sintesis asam lemak dalam hati, sehingga lemak yang terbentuk dan tersimpan dalam bentuk glikogen di hati berkurang (Hidayat, 2015). Dilihat dari fungsi hati sebagai organ yang berfungsi mengsekresik empedu untuk mengemulsi lemak, menetralisir racun (Blakely dan Bade, 1991). Selanjutnya menurut Alipin et al. (2016) Kurkuminoid temulawak memiliki aktivitas kolagoga yaitu berperan dalam meningkatkan produksi dan sekresi empedu dalam hati, merangsang keluarnya getah pancreas yang dapat meningkatkan metabolisme bahan pakan sumber karbohidrat, protein, dan lemak sehingga proses pencernaan berlangsung cepat dan optimal.

\section{KESIMPULAN}

Berdasarkan hasil penelitian dan pembahasan maka dapat disimpulkan bahwa pemberian ramuan herbal sampai 5
$\mathrm{mL}$ yang ditambahkan pada air minum tidak menyebabkan perubahan persentase karkas dan persentase hati namun pada pemberian $5 \mathrm{~mL}$ terjadi penurunan persentase lemak abdomen ayam kampung super.

\section{DAFTAR PUSTAKA}

Agustina, L., W. Ardiansya, dan Jamila. 2014. Peran ramuan herbal Labio-1 terhadap performa dan infeksi salmonella pullorum pada broiler. http://repository.unhas.ac. id/handle/123456789/10709.

Agustina, L. 2006. Penggunaan ramuan herbal sebagai Feed Additive untuk meningkatkan performans broiler. Pros. Lokakarya Nasional Inovasi Teknologi dalam Mendukung Usaha Ternak Unggas Berdaya Saing. 4 Agustus Semarang, Puslitbang Peternakan Bogor. Hlm. 47-52.

Alipin, K., R. Safitri, dan R. Kartasudjana. 2016. Suplementasi probiotik dan temulawak pada ayam pedaging terhadap populasi Salmonella $s p$ dan kolesterol darah. Fmipa unpad, Jurnal Veteriner 17(4): 582- 586.

Apritar, R. R. 2012. Optimalisasi Penggunaan Kombinasi dan Interval Pemeberian Ramuan Herbal Cair Terhadap Presentase Karkas dan Lemak Abdominal Broiler. SKRIPSI. Fakultas Pertanian UNHAS.

Bakrie, B., D. Andayani, M. Yanis dan D. Zainuddin. 2003. Pengaruh penambahan jamu ke dalam air minum terhadap preferensi konsumen dan mutu karkas ayam 
buras. Prosiding Seminar Nasional

Teknologi Peternakan Dan

Veteriner. September 2003.

Puslitbang Peternakan. Bogor.

Blakely. J dan D. H. Bade. 1991. Ilmu Peternakan. Diterjemahkan oleh Srigandono, Bambang. UGM Press, Yogyakarta.

Budiman, H., T. R. Ferasyi, Tapielaniari, M. N. Salim, U. Balqis dan M. Hambal. 2015. Pengamatan lesi mikroskopis pada hati ayam broiler yang dijual di pasar Lambaro Aceh Besar dan hubungannya dengan keberadaan mikroba. Jurnal Medika Veterinaria 9(1): $51-53$.

Cahyono, E.D., U. Atmomarsono, dan E. Suprijatna. 2012. Pengaruh penggunaan tepung jahe (Zingiber offinale) dalam ransum terhadap saluran pencernaan dan hati pada ayam kampung umur 12 minggu. Animal Agricultural Journal 1(1): $65-74$.

Daud, M., W. G. Pilliang, dan I. P. Kompiang, 2007. Persentase dankualitas karkas ayam pedaging yang diberi probiotik danprobiotik dalam ransum. JITV 12(3): 167174.

Dharmawati, S., N. Firahmi, dan Parwanto. 2013. Penambahan tepung bawang putih (Allium Sativum L) sebagai feed additif dalam ransum terhadap penampilan ayam pedaging (Garlic Allium sativum L). ZIRAA'AH 38(3): 17-22.

Djunu, S.S. dan E. J. Saleh. 2015. Penggunaan dedak padi difermentasi dengan cairan rumen dalam ransum terhadap bobot hidup, persentase karkas dan lemak abdominal, ayam kampung super. Laporan Penelitian. Fakultas Pertanian. UNG Gorontalo.
Harlin, F. R. 2013. Pengaruh Jumlah Dan Bentuk Ramuan Herbal Sebagai Imbuhan Pakan Terhadap Bobot Karkas, Lemak Abdominal Dan Kolesterol Darah Broiler. http://repository.unhas.ac.id/oai/req uest?verb=listRecord

Hidayat, C. 2015. Penurunan deposit lemak abdominal pada ayam pedaging melalui manajemen pakan. Journal WARTAZOA Vol. 25(3): 125-134.

Manuaba, I. B., N. W. Siti, dan N. M. S. Sukmawati. 2017. Pengaruh aditi sari daun papaya terfermentasi terhadap organ dalam ayam kampung. Fapet universitas udayana. Journal of Tropical Animal Science 5(1): 37-49.

Mustaqim, 2006. Persentase Bobot Karkas, Organ Dalam, Dan Lemak Abdomen Broiler Yang Diberi Imbuhan Tepung Daun Sambiloto (Andrographis paniculata Nees). Skripsi. Fakultas Peternakan Institut Pertanian Bogor. Bogor

Rahayu, I.H.S. dan C. Budiman. 2005. Pemanfaatan tanaman tradisional sebagai feed additive dalam upaya menciptakan budidaya ayam lokal ramah lingkungan. Lokakarya Nasional Inovasi Teknologi Pengembangan ayam lokal. Departement Ilmu Produksi dan Teknologi Ternak. FAPET IPB. Hal: 126-131.

Ramdani, I., D. Kardaya, dan Anggraeni. 2016. Pengaruh subtitusi pakan komersil dengan tepung ampas kelapa terhadap bobot potong dan bobot karkas ayam kampung. Jurnal Peternakan Nusantara Vol 2(1): 916

Resnawati, H. 2010. Bobot organ-organ tubuh pada ayam pedaging yang diberi pakan mengandung minyak biji saga (Adenanthera pavonina 
L.). Seminar Nasional Teknologi Peternakan dan Veteriner. Balai Penelitian Ternak, Bogor.

Sani, B. 2016. Panduan Sukses Beternak \& Bisnis Ayam Kampung Super. Pustaka Dianatara. Yogyakarta

Supomo, E., S. Syamsul, dan I. Ventyrina. 2016. Pemanfaatan ekstrak herbal terhadap produktifitas dan mutu ayam pedaging sebagai upaya ketahanan pangan di Kalimantan timur berbasis peternakan ramah lingkungan. Jurnal Ilmiah Manuntung, 2 (1), 93 - 98

Steel, R. G. D. and J. H. Torrie. 1991. Prinsip dan Prosedur Statistika.
Terjemahan B. Sumantri. PT. Gramedia Jakarta.

Syam, M. 2015. Analisis Berat Dan Kualitas Karkas Ayam Broiler Yang Diberikan Jamu Probiotik Dan Tanaman Herbal Melalui Air Minum. Jurnal Galung Tropika, 4(2): 74-80.

Zainuddin, D. 2006. Tanaman obat meningkatkan efisiensi pakan dan kesehatan ternak unggas. Lokakarya Nasional Inovasi teknologi dalam mendukung usaha ternak unggas berdaya saing. Balai Penelitian Ternak. Hal: 202-209. 